\title{
Donald L. Morton Memorial Lecture: the legacy of Donald Morton: past, present and future
}

\author{
Mark B. Faries $^{1}$ D
}

Received: 30 November 2020 / Accepted: 27 June 2021 / Published online: 18 July 2021

(c) The Author(s), under exclusive licence to Springer Nature B.V. 2021

\begin{abstract}
Donald L. Morton, MD persevered against great odds throughout his life and career. Beginning in the humblest of circumstances, he worked his way to the highest echelon of academic surgery, revolutionized surgical treatment of melanoma with innovations that rippled through the rest of oncology. His research led to dramatically improved disease staging while also decreasing morbidity. He stood as a champion of immunotherapy for many years when few others believed it would ever work. His greatest professional legacy, and the achievement of which he was most proud, is in the accomplishments of those he trained over his many years in the field.
\end{abstract}

Keywords Donald L. Morton · Sentinel lymph node · Immunotherapy · Metastasectomy

$\begin{array}{ll}\text { Abbreviations } \\ \text { BCG } & \text { Bacille Calmette Guerin } \\ \text { MSLT } & \text { Multicenter Selective Lymphadenectomy Trial } \\ \text { UCLA } & \text { University of California Los Angeles } \\ \text { NCI } & \text { National Cancer Institute }\end{array}$

It is a great honor to give the Donald L. Morton Memorial Lecture at the 8th International Symposium on Cancer Metastasis. Dr. Morton was a mentor to me and to innumerable others not only in surgical oncology, but in medicine more broadly. What he was able to accomplish, having been born into the humblest circumstances is truly remarkable. His achievements in oncology were far-reaching and include development of the sentinel lymph node biopsy technique, for which he is probably most well-known, as well as immunotherapy for cancer with both intralesional therapies and vaccine development. He was also a champion for surgical resection for patients with metastatic cancer. However, the

Presented at the 8th International Cancer Metastasis Congress in San Francisco, CA, USA from October 25-27, 2019 (http://www. cancermetastasis.org). To be published in an upcoming Special Issue of Clinical and Experimental Metastasis: Novel Frontiers in Cancer Metastasis.

Mark B. Faries

mfaries@theangelesclinic.org

1 The Angeles Clinic and Research Institute and Cedars Sinai Medical Center, Los Angeles, CA, USA professional achievement of which he was proudest was in the training of dozens of surgical oncologists through his career, who now carry his legacy forward into the future.

Donald Morton was born September 12, 1934 in Richwood, West Virginia in a house build by his father in the middle of the Great Depression. Richwood is remarkably isolated, as a tiny community located in the interior of the Monongahela National Forest. He attended Berea College in Kentucky, which was available to him without tuition. His early success enabled him to transfer to the University of California Berkley and then to go on to medical school at the University of California San Francisco. He moved to the National Cancer Institute in 1969 to become head of the tumor immunology Section before taking a position on the faculty at UCLA where he was the Chief of Surgical Oncology and the Chief of General Surgery, where he founded the John Wayne Cancer Clinic together with the Wayne family in memory of their father. Dr. Morton moved his team to Santa Monica in 1991, where he remained for the rest of his career (Fig. 1).

He founded one of the earliest surgical oncology fellowship training programs, which was one of the first to be accredited as soon as accreditation was established. In addition to the many surgeons and oncologists who consider Dr. Morton a mentor, he directly trained dozens of surgical oncologists, many who went on to become leaders in academic surgery in their own right (Table 1). I recall that, when I was a chief resident at the University of Pennsylvania, when Larry Kaiser became Chairman of the Department 


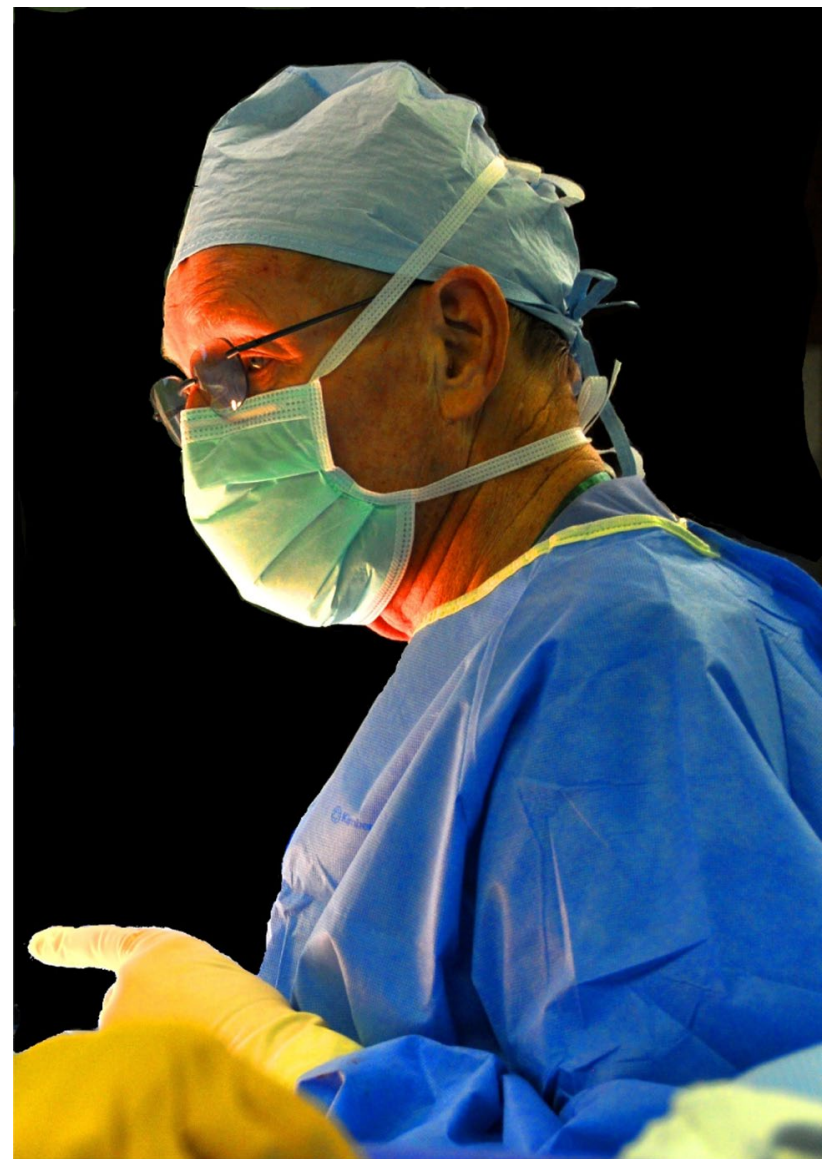

Fig. 1 Donald Morton operating and teaching

of Surgery there, he invited only two professional colleagues to speak at the ceremony that was held when he took the role, one of whom was Dr. Morton, which is a striking testament to the profound influence he had as a mentor. His pride in his trainees was always very evident, and he believed his accomplishments would be dwarfed by all that the next generation of surgeons, and the one after that would be able to do.

Dr. Morton's own personal accomplishments, however, were considerable (Table 2). Sentinel lymph node biopsy is probably the most well-known of these. Although the concept of a sentinel lymph node had been discussed by others dating back over 100 years, Dr. Morton's transformational breakthrough came from an understanding that the sentinel lymph node was determined not by its anatomic location, but as its functional status as the first node to receive lymphatic drainage from the primary tumor site. This concept developed from the efforts he and his team were making in refining elective lymph node dissection. In the era in which entire nodal basins were dissected at the time of initial treatment, some primary tumor locations such as the central trunk, did not have a clear single basin to target. To make this process more rational, they developed lymphoscintigraphy using colloidal gold particles as tracers [1]. These were injected at the primary tumor site and the target basin was revealed though imaging. Over time, with refinements in tracers and imaging technology, it became apparent that tracer was distributed not to an entire nodal basin, but more focally to only a single or small number of nodes within the basin. This observation led Dr. Morton to test injection of vital blue dyes to visualize, dissect and remove individual first echelon draining nodes, which he called sentinel. The research, first presented at the Society of Surgical Oncology in 1990, demonstrated the pathologic status of the sentinel node was representative of the status of the basin and that patients with negative sentinel nodes could be spared dissection [2].

As was typical, Dr. Morton immediately designed a randomized clinical trial to test this new procedure and brought surgeons in from around the United States and the world to learn the technique and participate in the trial. This first Multicenter Selective Lymphadenectomy Trial (MSLT-I) confirmed the value of the technique in revolutionizing staging and improving outcomes, including the survival of those patients who had nodal metastases [3]. Even before the first trial was completed, the second Multicenter Selective Lymphadenectomy Trial (MSLT-II) was being designed. This trial tested the role of completion lymph node dissection for patients with sentinel node metastases. Its findings, published after Dr. Morton's death, demonstrated that the sentinel node biopsy was the critical portion of initial treatment and that most patients could avoid nodal dissection safely, even with melanoma had spread to the sentinel node [4]. As a result of these trials, the standard of care for patients with melanoma now is radically different from what was the case before Dr. Morton's work and many thousands of patients have enjoyed the benefits of these advances. This is true not only for melanoma, but also for patients with breast cancer after the technique was brought to that malignancy by Dr. Morton's colleague (and mentee), Armando Giuliano.

Dr. Morton was also an early and vocal champion of immunotherapy for cancer [5]. For much of his career, he worked tirelessly on developing a vaccine for melanoma. This vaccine was an allogeneic, whole-cell vaccine administered with Bacille Calmette-Guerin (BCG) as an immune adjuvant. Unfortunately, at about the same time Dr. Morton was working to open clinical studies of his melanoma cell vaccine at the National Cancer Institute, controversy was swirling around an oncologist in New York named Chester Southam who had injected patients with varying quantities of cancer cells into patients, reportedly without their fully informed consent. According to Dr. Morton's recollection, in the context of that controversy, the Institutional Review Board at the NCI was initially unwilling to allow him to begin his trials injecting irradiated melanoma as a vaccine, even with informed patients. At about that time, though, a 
Table 1 Partial listing of mentees of Donald L. Morton

\begin{tabular}{|c|c|c|}
\hline Decade & Alumnus/Alumna & Current/Previous position(s) \\
\hline \multirow[t]{9}{*}{$1970 \mathrm{~s}$} & Armando E Giuliano, MD & $\begin{array}{l}\text { Vice Chair, Professor of Surgery, Cedars-Sinai } \\
\text { President, Society of Surgical Oncology, ACoSOG Breast Chair }\end{array}$ \\
\hline & James E. Goodnight, MD, PhD & Associate Dean, Chair of Surgery, Cancer Center Director, Professor of Surgery, UC Davis \\
\hline & E. Carmack Holmes & Longmire Professor and Chairman Emeritus, Chief of Cardiac Surgery, UCLA \\
\hline & Decio Rangel, MD & Chief of Surgical Oncology, Wadsworth VA, Chief of Surgical Oncology Tufts University \\
\hline & Jack A. Roth, MD & $\begin{array}{l}\text { Professor, Chief of Thoracic Surgery, MDACC } \\
\text { Head of Thoracic Oncology, National Cancer Institute Surgery Branch }\end{array}$ \\
\hline & Melvin Silverstein, MD & $\begin{array}{l}\text { Director, Hoag Breast Center, Gross Family Endowed Chair } \\
\text { Professor of Surgery, Breast Center Director USC Norris Cancer Center }\end{array}$ \\
\hline & Courtney M. Townsend, MD & $\begin{array}{l}\text { Robertson-Poth Distinguished Chair, UT Medical Branch } \\
\text { President, American College of Surgeons, American Surgical Association }\end{array}$ \\
\hline & Marshall M. Urist, MD & $\begin{array}{l}\text { Champ Lyons Professor of Surgery, Vice Chair, } \\
\text { Head of Surgical Oncology, University of Alabama, Director, American Board of Surgery }\end{array}$ \\
\hline & William C. Wood, MD & $\begin{array}{l}\text { Chief of Surgical Oncology, Massachusetts General Hospital, } \\
\text { Board of Governors, American College of Surgeons, } \\
\text { President, Society of Surgical Oncology } \\
\text { Professor, Emory University }\end{array}$ \\
\hline \multirow[t]{19}{*}{$1980 \mathrm{~s}$} & Samuel Ahn, MD & Professor of Surgery, Director Endovascular Program, UCLA \\
\hline & Carl Bertelsen, MD & Clinical Professor of Surgery, Stanford, Chair of Surgery, Good Samaritan Hospital \\
\hline & Martyn W. Burk, MD, PhD & Associate Professor of Surgery, SUNY Stony Brook \\
\hline & Steven D. Colquhoun, MD & Professor of Surgery, UC Davis, USC Norris Cancer Center \\
\hline & Edward R. Calkins, MD & Asst. Professor, University of Massachusetts \\
\hline & James Economou, $\mathrm{MD}, \mathrm{PhD}$ & $\begin{array}{l}\text { Vice Chancellor, Professor of Surgery, Chief of Surgical Oncology, UCLA } \\
\text { President, Society of Surgical Oncology }\end{array}$ \\
\hline & David M. Ehus, MD & Director Breast Surgery, Professor, Johns Hopkins University \\
\hline & Sanford J. Finck, MD & Asst. Professor of Surgery, Mayo Clinic Jacksonville \\
\hline & James Huth, MD & Professor of Surgery, Occidental Chair in Cancer Research, UT Southwestern \\
\hline & Peter C. Jones, MD & John Wayne Cancer Institute \\
\hline & Larry R. Kaiser, MD & $\begin{array}{l}\text { Dean, School of Medicine, President/CEO Temple Health System Medical Center } \\
\text { Professor, Chair of Surgery, University of Pennsylvania }\end{array}$ \\
\hline & David Krag, MD & SD Ireland Professor of Surgery, University of Vermont \\
\hline & Ann Marilyn Leitch, MD & ST Harris Distinguished Chair in Breast Surgery, Professor of Surgery, UT Southwestern \\
\hline & Barry D. Mann, MD & Professor of Surgery, Drexel University, Main Line Surgeons \\
\hline & Peter Naruns, MD & Stanford University /El Camino Hospital \\
\hline & S. David Nathanson, MD & Director Breast Care, Wayne State University \\
\hline & Allan W. Silberman, MD, PhD & $\begin{array}{l}\text { Robert J. and Suzanne Gottlieb Chair, Professor of Surgery, Clinical Chief of Surgical Oncology, } \\
\text { Cedars-Sinai }\end{array}$ \\
\hline & Vernon K. Sondak, MD & $\begin{array}{l}\text { Chair of Cutaneous Oncology, H. Lee Moffitt Cancer Center } \\
\text { Professor of Surgery, University of Michigan }\end{array}$ \\
\hline & Jan H. Wong, MD & $\begin{array}{l}\text { Professor of Surgery, East Carolina University } \\
\text { Chief of Surgical Oncology, Loma Linda University }\end{array}$ \\
\hline \multirow[t]{10}{*}{$1990 \mathrm{~s}$} & Peter D. Beitsch, MD & Dallas Surgical Group, President American Society of Breast Surgeons, \\
\hline & Anton J. Bilchik, MD, PhD & Chief of Gastrointestinal Research, Professor of Surgery, John Wayne Cancer Institute \\
\hline & Kyo U. Chu, MD & Geisinger Medical Center \\
\hline & Arnold M. Conforti, MD & Macon, GA \\
\hline & Paul S. Dale, MD & $\begin{array}{l}\text { Chief of Surgical Oncology, University of Missouri } \\
\text { Chief of Surgical Oncology, Mercer University }\end{array}$ \\
\hline & Leland J. Foshag, MD & Professor of Surgery, John Wayne Cancer Institute \\
\hline & J. Michael Guenther, MD & Edgewood, KY \\
\hline & Nora M. Hansen, MD & Division Chief, Breast Surgery, Professor of Surgery, Northwestern University \\
\hline & Eddy C. Hsueh, MD & Professor of Surgery, Saint Louis University \\
\hline & Kelly K. Hunt, MD & Chair, Dept. of Breast Surgical Oncology, Hamill Foundation Distinguished Professor, MDACC \\
\hline
\end{tabular}


Table 1 (continued)

\begin{tabular}{|c|c|c|}
\hline Decade & Alumnus/Alumna & Current/Previous position(s) \\
\hline & Pond R. Keleman, MD & Assoc. Professor of Surgery, NY Medical College \\
\hline & Mark C. Kelley, MD & Chief, Surgical Oncology, Assoc. Professor, Vanderbilt \\
\hline & Daniel Kirgan, MD & Professor, Chief of Surgical Oncology, University of Nevada \\
\hline & Thomas J. Lomis, MD & Director Valley Breast Care, Van Nuys, CA \\
\hline & David W. Ollila, MD & Mills Distinguished Professor of Surgery, University of North Carolina \\
\hline & Terry Sarantou, MD & $\begin{array}{l}\text { Levine Cancer Institute, Carolinas Healthcare } \\
\text { Board of Governors American College of Surgeons } \\
\text { Clinical Professor of Surgery, UNC Chapel Hill }\end{array}$ \\
\hline & Stephen G. Swisher, MD & $\begin{array}{l}\text { Head, Division of Surgery, Professor, Dept Chair, Charles A. LeMaistre Distinguished Chair, MD } \\
\text { Anderson }\end{array}$ \\
\hline & Lorraine Tafra, MD & Breast Director, Ann Arundel Medical Center \\
\hline \multirow[t]{36}{*}{ 2000s } & Farin Amersi, MD & Associate Professor, Director Surgical Residency, Cedars-Sinai \\
\hline & Richard J. Bleicher, MD & Director Breast Fellowship, Professor of Surgery, Fox Chase \\
\hline & Steven L. Chen, MD & Scripps Clinic, President American Society of Breast Surgery \\
\hline & Matthew Chung, MD & Surgery Program Director, Michigan State University \\
\hline & W. Charles Conway, MD & UCSB/Cottage Hospital, Santa Barbara \\
\hline & L. Andrew DiFronzo, MD & Chief of Surgery, Kaiser Los Angeles \\
\hline & Mark B. Faries, MD & Co-Director, Cutaneous Oncology, Professor of Surgery, Cedars-Sinai \\
\hline & Jennifer R. Garreau, MD & Legacy Health, Asst. Professor, Oregon Health Science University \\
\hline & Baiba J. Grube, MD & Assoc. Professor of Surgery, Yale University \\
\hline & Seza A. Gulec, MD & Professor, Chief Surgical Oncology, Florida Int'1 University \\
\hline & Phillip I. Haigh, MD & Assistant Chief of Surgery, Kaiser Los Angeles \\
\hline & Douglas Iddings, DO & Flint, MI \\
\hline & Alan S. Kadison, MD & Asst. Professor of Surgery, Hofstra University \\
\hline & John C. Kang, MD & Los Angeles, CA \\
\hline & Joseph Kim, MD & Professor of Surgery, Chief of Surgical Oncology, University of Kentucky \\
\hline & Laura Kruper, MD & Director Women’s Center, Assoc. Professor, City of Hope \\
\hline & Chris C. Lee, MD & Hillsboro, OR \\
\hline & Jonathan H. Lee, MD & Medical Director, Northside Melanoma Specialists \\
\hline & David A. Litvak, MD & Chair, Dept of Surgery, Cancer Treatment Centers of America, Western \\
\hline & Steven Martinez, MD & Everett Clinic \\
\hline & Michael B. Nicholl, MD & Asst. Professor, South Texas VA \\
\hline & Dean T. Nora, MD & Kaiser, Woodland Hills, CA \\
\hline & D. Michael Rose, MD & Richmond, VA \\
\hline & Randall P. Scheri, MD & Assoc. Professor,, Chief of Endocrine Surgery, Duke University \\
\hline & Perry Shen, MD & Program Director, Professor of Surgery, Wake Forest University \\
\hline & Bret Tabak, MD & Director, Melanoma/Sarcoma, Breast Fellowship, Columbia Univ \\
\hline & Simon Telian, MD & Fort Bragg, NC \\
\hline & Alicia Terando, MD & Assoc. Professor, University of Southern California \\
\hline & Steven D. Trocha, MD & Assistant Professor Clinical Surgery, Clemson, University Greenville Health System \\
\hline & George J. Tsioulias, MD, PhD & Mount Sinai, Queens, NY \\
\hline & Robert Wascher, MD & Clinical Professor of Surgery, University of Arizona, Cancer Treatment Centers of America, Western \\
\hline & Nabil Wasif, MD & Program Director General Surgery, Assoc. Professor, Mayo Clinic, AZ \\
\hline & Lori L. Wilson, MD & Assoc. Professor, Chief of Surgical Oncology, Howard University \\
\hline & Thomas F. Wood, MD & Kaiser, Woodland Hills, CA \\
\hline & Katherine Yao, MD & $\begin{array}{l}\text { Chief of Surgical Oncology, Vice Chair of Research, Clinical Associate Professor of Surgery, North- } \\
\text { shore Univ. Hospital }\end{array}$ \\
\hline & Shawn Young, MD & Dir. Surgical Oncology, SJH Cancer Center, Denver, CO \\
\hline \multirow[t]{2}{*}{$2010 \mathrm{~s}$} & Elizabeth A. Arena, MD & Los Angeles, CA \\
\hline & Joslyn Albright, MD & Christ Advocate Hospital, Oak Lawn, IL \\
\hline
\end{tabular}


Table 1 (continued)

\begin{tabular}{lll}
\hline Decade & Alumnus/Alumna & Current/Previous position(s) \\
\hline Sanjay Bagaria, MD & Assoc. Professor of Surgery, Mayo Clinic, Jacksonville \\
Connie Chu, MD & Royal Columbian Hospital, Vancouver, BC \\
Gary B. Deutsch, MD & Asst. Professor of Surgery, Hofstra University \\
Ani Fleisig, MD & Burien, WA \\
Manabu Fujita, MD & Thousand Oaks, CA \\
Danielle M. Hari, MD & Chief of Surgical Oncology, Asst. Professor, Harbor-UCLA \\
Jason Hiles, MD & Fort Bragg, NC \\
J. Harrison Howard, MD & Assoc. Professor, University of Alabama \\
Hamed Kargozaran, MD & Kaiser, West Los Angeles \\
Travis Kidner, MD & Beverly Hills, CA \\
Daniel Kirchoff, MD & Charleston, SC \\
Simon Lavotschkin, MD & Sharp Hospital, San Diego, CA \\
Anna Leung, MD & Kaiser, Los Angeles \\
Jennifer H. Lim, MD & Kaiser Los Angeles \\
Junko Ozao-Choy, MD & Vice Chair, Research, Asst. Professor of Surgery, Harbor-UCLA \\
Victoria O'Connor, MD & Kaiser Los Angeles \\
Partha Ray, MD & Urbana, IL \\
Shawn Steen, MD & Ventura, CA \\
\hline
\end{tabular}

Table 2 Selected landmark publications of Dr. Morton's career

\begin{tabular}{|c|c|c|}
\hline Date & Article & Description \\
\hline 1968 & $\begin{array}{l}\text { Demonstration of Antibodies Against Human Malignant Melanoma } \\
\text { by Immunofluorescence }\{\text { Morton, } 1968 \# 481\}\end{array}$ & $\begin{array}{l}\text { Early description of identification of tumor-associated antigens in } \\
\text { human melanomas }\end{array}$ \\
\hline 1970 & $\begin{array}{l}\text { Immunological factors which influence response to immunotherapy } \\
\text { in malignant melanoma }\{\text { Morton, } 1970 \# 1871\}\end{array}$ & $\begin{array}{l}\text { First report of successful BCG immunotherapy in melanoma (45 } \\
\text { patient series published in 1974) [5] }\end{array}$ \\
\hline 1977 & A rational approach to the surgical management of melanoma [1] & $\begin{array}{l}\text { First publication on lymphoscintigraphy to determine lymphatic } \\
\text { drainage of melanoma }\end{array}$ \\
\hline 1988 & $\begin{array}{l}\text { Occult tumor cells in the lymph nodes of patients with pathologi- } \\
\text { cal stage I malignant melanoma. An immunohistological study } \\
\{\text { Cochran, } 1988 \# 1950\}\end{array}$ & $\begin{array}{l}\text { First report of detection of occult tumor cells in regional lymph } \\
\text { nodes by immunohistochemistry }\end{array}$ \\
\hline 1992 & $\begin{array}{l}\text { Technical details of intraoperative lymphatic mapping for early stage } \\
\text { melanoma [2] }\end{array}$ & $\begin{array}{l}\text { Seminal report of sentinel lymph node biopsy technique in mela- } \\
\text { noma }\end{array}$ \\
\hline 1992 & $\begin{array}{l}\text { Prolongation of survival in metastatic melanoma after active specific } \\
\text { immunotherapy with a new polyvalent melanoma vaccine }\{\text { Mor- } \\
\text { ton, } 1992 \# 14\}\end{array}$ & First report of Dr. Morton's allogeneic whole cell vaccine \\
\hline 2005 & Sentinel node biopsy for early-stage melanoma [3] & $\begin{array}{l}\text { First report of results of the first Multicenter Selective Lymphad- } \\
\text { enectomy Trial (MSLT-I) }\end{array}$ \\
\hline 2014 & $\begin{array}{l}\text { Final trial report of sentinel-node biopsy versus nodal observation in } \\
\text { melanoma \{Morton, } 2014 \# 1622\}\end{array}$ & Long-term results of MSLT-I study \\
\hline 2017 & $\begin{array}{l}\text { Completion dissection or observation for sentinel-node metastasis in } \\
\text { melanoma [4] }\end{array}$ & Initial report from the second MSLT study \\
\hline
\end{tabular}

patient presented to him with extensive in-transit melanoma metastases in her arm whose treatment allowed proof of principle. Her contralateral arm had been paralyzed by polio, and she was not willing to undergo an amputation of her fully functional arm as treatment. Dr. Morton realized there was no need to inject melanoma cells, as the patient's tumor cells were already present, but that provision of immune stimulation to those sites with BCG might accomplish the same end. He injected BCG into several of the metastases, recreating the conditions he had planned to use for his vaccine protocol. After a series of injections, the patient went on to a complete clinical response and remained free of evidence of disease for many years thereafter. Although BCG has now been eclipsed by modern checkpoint inhibitors and 
Fig. 2 Intralesional immunotherapy with Bacille CalmetteGuerin. The patient is a 66 -yearold woman with innumerable dermal in-transit metastases in her thigh, buttock and hip. A Sensitization to BCG followed by intralesional injections into a subset of the lesions $(\mathbf{B})$ led to complete regression of injected and non-injected lesions over 12 weeks, with only pigment remaining $(\mathbf{C})$. She remained without evidence of disease at her last follow up 3 years later
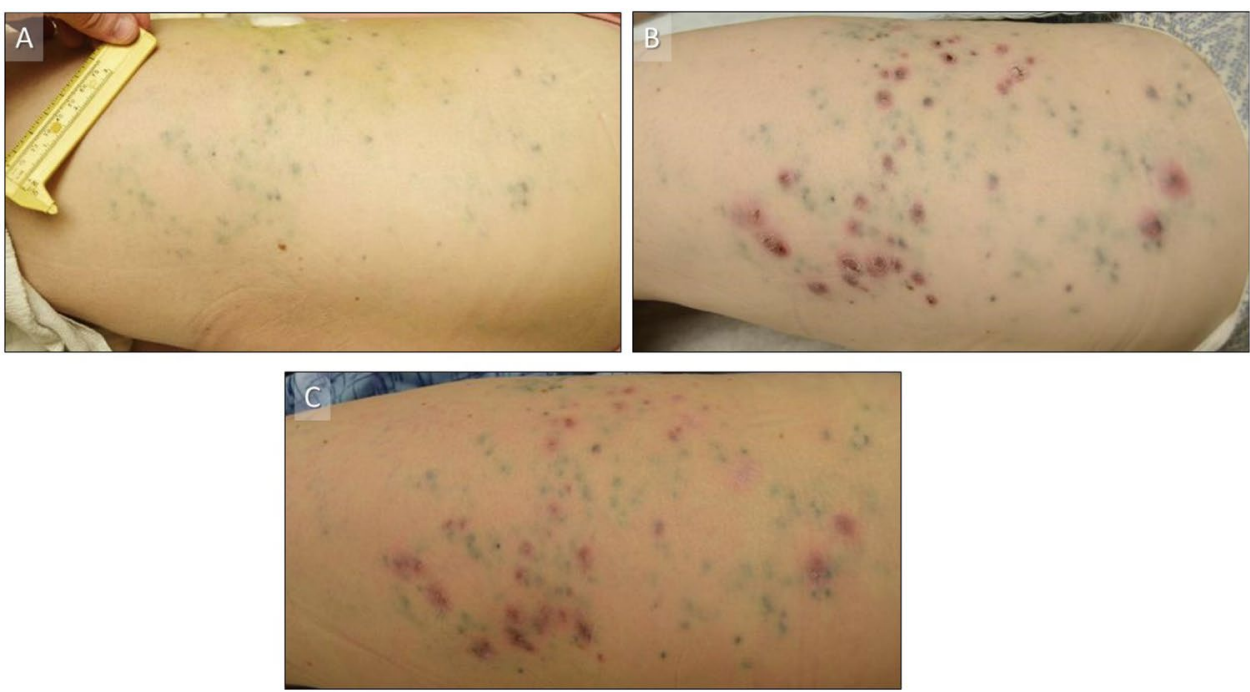

cytokines, as a proof of concept it helped keep the hope of an effective immune therapy alive while research continued. It may still be used in selected cases even today [6] (Fig. 2).

Metastasectomy for melanoma was also a concept Dr. Morton felt strongly about [7]. He was often quoted as saying that "Overall data suggest initial treatment of choice for Stage IV metastatic melanoma to single or multiple sites should be surgery, followed by surgery, followed by surgery again." A recent review of resection for stage IV melanoma reaffirms his earlier observations that patients who can have complete resection of metastases, even in advanced stage disease, can enjoy long-term survival if they are properly selected [8]. This appears to still be true in the era of modern, effective systemic therapies. The advent of those therapies, though, has made treatment decisions more complex, as there are patients who become candidates for resection after an initial period of systemic therapy, and others form whom surgery, though possible at the time of diagnosis, may be better served with an initial period of medical treatment. However, the principal that surgery can add to the care of patients even after hematogenous dissemination remains an important one to preserve as melanoma care evolves.

As a member of the group of surgeons trained by Dr. Morton, I remain committed to carrying the discoveries he made further into the future. He remained eternally optimistic and was never discouraged even in the face of initial failure. His presentation of the sentinel node technique to the Society of Surgical Oncology was followed by almost 2 years of failed efforts to gain acceptance of the manuscript related to that work for publication. Eventually it was published and went on to become one of the most highly cited papers in oncology [9]. Similarly, when the randomized Phase 3 trials evaluating his vaccine failed to show a survival benefit in the vaccine arm. He immediately saw the glass as half full, since the survivals in both the vaccine and placebo groups was over $40 \%$ at 5-years, which for Stage IV melanoma was unheard of at the time [10]. Rather than being defeated, he began designing the next clinical trial to determine whether the favorable outcomes were due to trial selection, surgical therapy or adjuvant BCG injections, which both groups had received.

In closing, I would like to again express my gratitude for the opportunity to deliver the Morton Lecture. I know that his legacy will continue through generations of surgeons and oncologists well into the future.

\section{Declarations}

Conflict of interest The author has no conflicts of interest relevant to this material.

\section{References}

1. Holmes E, Moseley H, Morton D et al (1977) A rational approach to the surgical management of melanoma. Ann Surg 186:481-490

2. Morton D, Wen D, Wong J et al (1992) Technical details of intraoperative lymphatic mapping for early stage melanoma. Arch Surg 127:392-399

3. Morton D, Cochran A, Thompson J et al (2005) Sentinel node biopsy for early-stage melanoma: accuracy and morbidity in MSLT-1, an interanational multicenter trial. Ann Surg 242:302-311

4. Faries MB, Thompson JF, Cochran AJ et al (2017) Completion dissection or observation for sentinel-node metastasis in melanoma. N Engl J Med 376:2211-2222

5. Morton D, Eilber F, Holmes E et al (1974) BCG immunotherapy of malignant melanoma: summary of a seven-year experience. Ann Surg 180:635-643

6. Kidner TB, Morton DL, Lee DJ et al (2012) Combined intralesional Bacille Calmette-Guerin (BCG) and topical imiquimod for in-transit melanoma. J Immunother 35:716-720 
7. Howard JH, Thompson JF, Mozzillo N et al (2012) Metastasectomy for distant metastatic melanoma: analysis of data from the first Multicenter Selective Lymphadenectomy Trial (MSLT-I). Ann Surg Oncol 19:2547-2555

8. Nelson DW, Fischer TD, Graff-Baker AN et al (2019) Impact of effective systemic therapy on metastasectomy in stage IV melanoma: a matched-pair analysis. Ann Surg Oncol 26:4610-4618

9. Balch CM, Roh MS, Suzanne Klimberg V et al (2014) In memoriam: Donald L. Morton, MD (1934-2014): an icon in surgical oncology: past president, society of surgical oncology (19921993) and associate editor, annals of surgical oncology (19932014). Ann Surg Oncol 21:1413-1416
10. Morton DL, Mozzillo N, Thompson JF et al (2007) An international, randomized, phase III trial of bacillus Calmette-Guerin (BCG) plus allogeneic melanoma vaccine (MCV) or placebo after compete resection of melanoma metastatic to regional or distant sites. J Clin Oncol. https://doi.org/10.1200/jco.2007.25.18_suppl. 8508

Publisher's Note Springer Nature remains neutral with regard to jurisdictional claims in published maps and institutional affiliations. 